\title{
The European Community and Yugoslavia in the Late Cold War Years, 1976-1989
}

\author{
Benedetto ZACCARIA
}

\begin{abstract}
Most existing studies on EC/EU policy towards Yugoslavia only focus on the period after the outbreak of the Yugoslav wars in the 1990s. This essay sheds new light on the relations between the European Community (EC) and Yugoslavia in the preceding fifteen years, which coincided with the renewal of Cold War tensions and the eventual demise of the Communist regimes in East-Central Europe. Drawing on newly declassified sources from several Community and national archives, it shows that, from 1976 to 1989, the EC established firmly based political relations with Yugoslavia, which were primarily determined, and constrained, by the need to prevent the expansion of Soviet influence in the Balkans and to foster détente in Europe.
\end{abstract}

Keywords: European Community, Yugoslavia, Non-alignment, Mediterranean, détente.

\section{Introduction}

As noted in 2004 by the German scholar Rafael Biermann, the large number of studies on EC/EU policy towards Yugoslavia after the outbreak of the 1990s wars contrasts with the silence of the scholarly front on relations between the EC and Yugoslavia before the demise of the latter. ${ }^{1}$ The EC's Yugoslav policy before 1991 has commonly been described as a "policy of neglect", which may be summarised as follows: a) ill-advised support to the Yugoslav federal government, to the detriment of the single federal republics 3 ; b) diplomatic ignorance and unawareness about Yugoslavia's fragile internal situation ${ }^{4}$; c) idea of Yugoslavia as a simple trading partner and labour exporter. ${ }^{5}$ However, analysis of newly declassified

1 Rafael Biermann, "Back to the roots. The European Community and the Dissolution of Yugoslavia - Policies under the Impact of Global Sea-Change" in Journal of European Integration History, No. 1, Vol. 10, 2004, 29. On the scholarly debate on Yugoslavia's collapse, see: Sabrina P. Ramet, Thinking about Yugoslavia. Scholarly Debates about the Yugoslav Breakup and the Wars in Bosnia and Kosovo, New York: Cambridge University Press, 2005.

2 Biermann, "Back to the roots", op. cit., p. 49.

3 Stevan K. Pavlowitch, "Yugoslavia: Why did It Collapse?", in Vassilis K. Fouskas (ed.), The Politics of Conflict, London: Routledge, 2007, pp. 147-154; Jože Pirjevec, Le guerre jugoslave 1991-1999, Torino: Einaudi, 2001, 49; Sonia Lucarelli, Europe and the Breakup of Yugoslavia. A Political Failure in Search of Scholarly Explanation, The Hague: Kluwer Law International, 2000, pp. 15-18.

4 Viktor Meier, Yugoslavia: A History of its demise, London/New York: Routledge, 1999; James Gow, Triumph of the Lack of Will: International Diplomacy and the Yugoslav War, London: C. Hurst \& Co., 2003.

5 Branislav Radeljić, Europe and the Collapse of Yugoslavia. The role of Non-State Actors and European Diplomacy, London/New York: I. B. Tauris, 2012, p. 2. 
sources from several Community and national archives offers new interpretations which challenge the above-mentioned views. ${ }^{6}$ This essay argues that, since 1976, the EC established with Yugoslavia ongoing relations, which were based on sound political rationale. Indeed, the EC's policy towards Yugoslavia was primarily motivated by the need to prevent the expansion of Soviet influence in the Balkans and the Mediterranean. As it will be demonstrated in the following sections, the Cold War framework deeply affected EC's policy towards Yugoslavia until the very end of the bloc-to-bloc confrontation in Europe.

\section{The origins of EC-Yugoslav relations (1968-1975)}

The Cold War framework had shaped relations between the Western bloc and Yugoslavia since the 1948 Tito-Stalin split. Since then, the US, UK and France kept Tito "afloat" by economic and military means to contain Soviet influence in the Balkans, which would have seriously altered the post-World War II balance of power in Europe. ${ }^{8}$ As far as the EC was concerned, the first coordinated policy towards Yugoslavia goes back to 1968. The EC Commission entered into trade negotiations with Belgrade after the Warsaw Pact intervention in Czechoslovakia, which was regarded by EC member states (i.e. the Six) as a potential threat to other Socialist countries, including Yugoslavia. ${ }^{9}$ Negotiations were influenced by the Six's will to demonstrate their support to the latter's economic stability. ${ }^{10}$ The first trade agreement, signed in March 1970, was non-preferential in nature, which suited Yugoslavia's non-aligned status and aimed to fix the imbalance of EC-Yugoslav trade. ${ }^{11}$ The EC took advantage of the new relationship with

6 This chapter draws primarily on archival sources from the following archives: Historical Archives of the European Union (Florence); Historical Archives of the European Commission (Brussels); Archives of the Council of the European Union (Brussels); UK National Archives (Kew); Archives du Ministère des Affaires Étrangères (La Courneuve, Paris). For comments and suggestions on earlier drafts of this essay I am grateful to Angela Romano, Maria Elena Cavallaro and Antonio Varsori.

7 Lorraine M. Lees, Keeping Tito Afloat: The United States, Yugoslavia and the Cold War, University Park, PA: Penn State University Press, 1997.

8 Beatrice Heuser, Western "Containment" Policies in the Cold War. The Yugoslav Case, 1948-1953, London/New York: Routledge, 1989.

9 Historical Archives of the European Union, Florence (HAEU), EM (Edoardo Martino's papers), Box No. 65, Direction Général du Commerce Extérieur, Note à l'attention de M. Le President Rey, Bruxelles, 12 September 1968.

10 French Foreign Ministry Collections, Entretiens et messages, Vol. 5, Compte Rendu des Entretiens de M. Gaja et de M. Puaux, Rome 1er Octobre 1968; HAEU, EM, 65, Négociations entre la CEE et la Yougoslavie - Communication de la Commission, Bruxelles, 31 October 1968.

11 Historical Archives of the European Commission (HAEC), BAC 31978 871, Conseil des Communautés Européennes, Communication à la Presse, 19 March 1970. See also: Panos Tsakaloyannis, "The Politics and Economics of EEC-Yugoslav Relations", in Journal of 
Yugoslavia to relaunch its image within the non-aligned movement (NAM) as an international actor with a well-defined identity. This emerged when the President of the EC Commission, Franco Maria Malfatti, visited Tito in June 1971. During the meeting with the Yugoslav leader, Malfatti stressed the new course of the EC as an "open Community (...) with a deep concern for the problems of her partners" by highlighting the value of the EC's Generalised System of Preferences (GSP) to all developing countries. ${ }^{12}$ Malfatti emphasised the Community's views on the process of détente, which suited Yugoslavia's non-aligned stance well: "We do not want to be a bloc but, although faithful to our friends, we want to overcome the strict and sterile logic of the blocs. (...) The vitality of the Community is fed by the new international environment in which new and flexible structures are replacing the virulence and the total character of the Cold War". ${ }^{13}$ The common goal of a genuinely European détente was emphasised by the cooperation between the EC Nine and the Neutral and non-aligned countries during the Conference on Security and Cooperation in Europe (1972-1975). ${ }^{14}$

However, in the early 1970s, EC-Yugoslav relations were affected by the stagnation of bilateral trade. Yugoslavia's trade deficit deteriorated as an effect of the Community's protectionist measures, urged by several member states to face the economic consequences of the 1973 Oil Shock. Therefore, Yugoslavia was forced to improve its trade with the Soviet bloc countries. Yet, the shift of trade flows from the EC to the Comecon area was viewed with deep concern in Belgrade. On 10 June 1975, the Yugoslav government sent the EC an official Memorandum, in which the Community was urged to facilitate the access of Yugoslav exports, to prevent Belgrade's dependency on the Comecon market. ${ }^{15}$

European Integration, Vol. 5, No.1, 1981, pp. 29-52; Stephen Holt and Ken Stapleton, "Yugoslavia and The European Community 1958-1970", in Journal of Common Market Studies, No. 1, Vol. 10, 1971, pp. 47-57; Patrick F. R. Artisien and Stephen Holt, "Yugoslavia and the EEC in the 1970s", in Journal of Common Market Studies, No. 4, Vol. 18, 1980, pp. 355-369.

12 HAEU, EN (Emile Noel's papers), 1250, Note a l'attention de Monsieur Sigrist, Voyage officiel en Yougoslavie, 30 June 1971; HAEC, BAC 971986 15, Note de dossier, La Yougoslavie, principale bénéficiaire des préférences généralisées de la Communauté, Bruxelles, le 22 janvier 1975.

13 HAEU, EN 1518, Progetto di brindisi del Presidente Malfatti al Pranzo ufficiale offerto dal Ministro Granfil, Belgrado, 25 June 1971.

14 Archives du Ministère des Affaires Étrangères (AMAE), Direction Europe 1971-1976 (DE 71-76), Carton 3759, Note, La Yougoslavie et la CSCE, Paris, le 5 décembre 1974; See Angela Romano, From Détente in Europe to European Détente: How the West Shaped the Helsinki CSCE, Bruxelles: Peter Lang, 2009, pp. 128-131; Jože Pirjevec, "Yugoslavia and the Helsinki Process", in Carla Meneguzzi Rostagni (ed.), The Helsinki Process. A Historical Reappraisal, Padova: CEDAM, 2004, pp. 87-95.

15 HAEC, BAC 481984 662, Note à l'attention de Monsieur E. Noel, Secrétaire Général, Bruxelles, le 16 VI 1975. 
The EC Nine's initial reluctance to meet Yugoslavia's requests was overcome due to the decline of the process of the superpower détente, which had dominated international relations during the first half of the $1970 \mathrm{~s} .{ }^{16}$ The fall of détente implied the resurgence of Western fears of a Soviet "grand design" on the global stage. ${ }^{17}$ The installation of SS-20 missiles in Warsaw pact territories raised confrontation also in the European continent. ${ }^{18}$ Yugoslavia was in the midst of these tensions. In fact, since the late 1960 s, NATO military experts had been discussing potential Soviet plans to regain positions in the Balkans and the Mediterranean basin. ${ }^{19}$ In the aftermath of the 1973 Arab-Israeli war and the end of Soviet-Egyptian military cooperation, Belgrade was seen as a potential victim of Soviet pressures, because of the strategic position of the Adriatic ports in Croatia and Montenegro. ${ }^{20}$ Yugoslavia's international weakness was also revealed by two other elements. The first was the mounting crisis of Yugoslavia's leadership within the NAM which, since the early $1960 \mathrm{~s}$, had represented one of the starkest symbols of Belgrade's international autonomy. In particular, the EC Nine were worried about the emergence within the Movement of a pro-Soviet faction headed by Cuba. ${ }^{21}$ The second element concerned alarming perspectives for the post-Tito era. Most analysis elaborated by Western embassies in Belgrade about the question: "After Tito, what?" depicted disquieting scenarios for Yugoslavia's future. ${ }^{22}$ Although the direct intervention of the USSR in

16 Raymond L. Garthoff, Détente and Confrontation: American-Soviet Relations from Nixon to Reagan, Washington D.C.: Brookings Institutions, 1985, pp. 849-886; Odd Arne Westad (ed.), The Fall of Détente: Soviet-American Relations during the Carter Years, Oslo: Scandinavian University Press, 1997; Leopoldo Nuti (ed.), "The Crisis of Détente in Europe. From Helsinki to Gorbachev, London/New York: Routledge, 2009.

17 Olav Njølstad, "The collapse of superpower détente, 1975-1980", in Melvyn P. Leffler and Odd Arne Westad (eds.), The Cambridge History of the Cold War, Vol. III, Cambridge: Cambridge University Press, 2010, p. 142.

18 Federico Romero, Storia della guerra fredda. L'ultimo conflitto per l'Europa, Torino: Einaudi, 2009, p. 270.

19 The National Archives (TNA), FCO 28/2962, Yugoslav/Soviet Relations, British Embassy Belgrade, 8 September 1976, Confidential; Akten zur Auswärtigen Politik der Bundesrepublik Deutschland 1976, doc. 207 and 221. See also Effie G. H. Pedaliu, “'A Sea of Confusion': The Mediterranean and Détente, 1969-1974”, in Diplomatic History, No. 4, Vol. 33, 2009, pp. 735-750.

20 TNA, FCO 28/2119, Parliamentary Under-Secretary of State for Defence for the Royal Air Force, 16 August 1972, Confidential.

21 AMAE, DE 76-80, 4845, Note, Réunion ministérielle du Bureau de coordination des pays non-alignés, Paris, le 7 Juin 1978; Note de Synthèse, Visite du Président de la République en Yougoslavie (6-7 Décembre 1976), Paris, le 24 Novembre 1976.

22 TNA, FCO 28/2119, Bilateral discussions with the Italians, 5 October 1972; The outlook for Yugoslavia, 26 October 1972; HAEC, BAC 971986 19, Notes de Synthèse sur le problème 
Yugoslav affairs was considered to be unlikely, Moscow was considered interested in favouring the emergence of pro-Soviet forces in Yugoslavia, able to exploit interrepublican rivalries and weaken the Balkan state's unity and stability. ${ }^{23}$

In the mid-1970s, the EC Nine and their NATO allies were therefore confronted with the following question: how to manage the rise of Soviet pressure towards Yugoslavia? The issue had been initially discussed within the NATO framework, in which national representatives agreed that no discussions on Yugoslavia's situation should be publicly undertaken within the Alliance and that no official statements on that topic should be released to the Western media. ${ }^{24}$ This would indeed lead to confrontation with Moscow and give the USSR a pretext for intervening in turn in Yugoslavia's internal affairs. ${ }^{25}$ As declared by a French diplomat to his EC colleagues in November 1976, the West should respect Yugoslavia's non-aligned position and peculiar social system: "Une attitude contraire aurait des conséquences désastreuses, car elle ferait tomber les barrières qui existent actuellement contre une éventuelle intervention russe, mais ce qui est plus grave, raidirait également l'attitude yougoslave elle-même, en détruisant ce qui constitue leur ciment national et donc en les incitant à basculer dans l'autre camp (...) En outre, une attitude trop 'impérialiste' de la part des pays occidentaux, non seulement ferait peser sur la Yougoslavie le risque de l'intervention russe, mais aussi nous ferait perdre sur le front des pays du tiers-monde un interlocuteur essentiel en tant que tête de pont". ${ }^{26}$ Hence, there was the need to find new ways of strengthening Western links with Belgrade by more discreet and subtle means which should formally respect Yugoslavia's autonomy. One of these was the development of relations between the EC and Yugoslavia. ${ }^{27}$ Thanks to its newly acquired competence in the commercial sphere, the EC Commission could indeed act as a porte-parole of the Nine and establish useful contacts with Belgrade in a "low profile" way. ${ }^{28}$

Yougoslave, Novembre 1976; AMAE, DE 71-76, 3761, Note, La Yougoslavie et l'Union Soviétique, Paris, le 29 mars 1971; AMAE, DE 71-76, 3759, De la politique de l'Europe des Neuf et de la France envers la Yougoslavie, Belgrade, le 12 Décembre 1974; TNA, FCO 28/2967, NATO Political Consultations-Yugoslavia, 10 November 1976.

23 TNA, FCO 28/2967, Yugoslavia: Discussion among permanent representatives to NATO, 19 October 1976.

24 AMAE, DE 71-76, 3760, Commentaires sur la position de l'OTAN vis-à-vis de la Grèce et de la Yougoslavie, Bruxelles, le 2 Octobre 1974; TNA, FCO 28/2965, Call by Yugoslav Ambassador, 20 October 1976; FCO 28/2962, United Kingdom delegation to NATO, Soviet interest in Yugoslav port facilities, 27 August 1976; TNA, FCO 28/2813, Changes in the threat to NATO and options for UK Reactions arising from Warsaw Pact pressures on Yugoslavia, 3 June 1975.

25 TNA, FCO 28/2412, Yugoslavia: Possible future instability, 8 November 1973.

26 HAEC, BAC 971986 19, Notes de Synthèse sur le problème Yougoslave, Novembre 1976.

27 Akten zur Auswärtigen Politik der Bundesrepublik Deutschland 1976, doc. 322.

28 TNA, FCO 28/3166, EEC/Yugoslavia, Note by the Foreign and Commonwealth Office, 26 July 1976; Prime Minister, Yugoslavia and the EEC, 10 June 1976. For the contemporary 
This is why after 1975 the Yugoslav issue was discussed with new impetus within Community Brussels. From May to October 1976, several meetings between EC and Yugoslav officials took place in Brussels to relaunch bilateral relations. ${ }^{29}$ On 12 October 1976, Pierre Duchateau, director of the Directorate General for External Relations (DG I) of the EC Commission, met the Yugoslav ambassador to the EC. Discussion focused on relations between Yugoslavia and the USSR in the perspective of the post-Tito era. According to Duchateau: "Le raisonnement yougoslave est que les Russes n'interviendront [in Yugoslavia] que s'ils sont sûrs de réussir. C'est pourquoi tout le calcul yougoslave est de prendre les assurances à l'Ouest par n'importe quel moyen de façon à dissuader les Russes dans leur souci d'intervenir". ${ }^{30}$ At the end of October 1976, Roland de Kergorlay, deputy director of DG I, went to Belgrade, where he met the Yugoslav representatives in charge of relations with the Community. Once back from his mission, he urged the Nine to give Yugoslavia a formal assurance about EC interest in developing bilateral relations. ${ }^{31}$ De Kergorlay's views were supported by the British Secretary of State, Anthony Crosland, who, after visiting Yugoslavia in early November 1976, emphasised to his EC colleagues the need for the Community to improve relations with Belgrade in order to sustain Yugoslavia's unity, independence, and stability. ${ }^{32}$

A few weeks later, on 15 and 16 November 1976, USSR leader Leonid Brezhnev visited Belgrade..$^{33}$ The visit aroused Western distress, for two main reasons. The first was Moscow's interest in obtaining access to Yugoslavia's Adriatic port facilities. The second concerned Brezhnev's alleged plans to establish closer economic relations with Belgrade in the perspective of the post-Tito era. ${ }^{34}$ In the eyes of French diplomats, for example, these were clear signs of Soviet leaders' long term objective of bringing Yugoslavia back into the bloc. The French highlighted that: "L'avantage que représenterait le contrôle d'un pays dont la position géographique au milieu du rivage septentrional de la Méditerranée est stratégiquement importante, est évident. Les perspectives qu'ouvrirait un tel contrôle pour le renforcement

action of the EC in other Mediterranean scenarios, see the monothematic issue of the Journal of European Integration History, No. 1, Vol. 15, 2009.

29 TNA, FCO 28/3166, Record of meeting between the Minister of State for foreign and Commonwealth Affairs and the Yugoslav Federal Secretary for Foreign Affairs, 5 October 1977.

30 HAEC, BAC 971986 19, Note à l'attention de Monsieur de Kergorlay, Compte rendu d'un déjeuner avec M. Tomasevic le 12 Octobre, 13 Octobre 1976.

31 TNA, FCO 28/2971, Council of Ministers (Foreign Affairs), 18/19 October, Luxembourg, EEC/Yugoslavia; HAEC, BAC 2501980 501, Note de Dossier, Compte rendu des entretiens exploratoires de M. de Kergorlay à Belgrade, Bruxelles, 28 October 1976, Secret.

32 AMAE, DE 76-80, 4835, Note, Politique extérieure de la Yougoslavie, Paris, le 4 octobre 1977.

33 TNA, FCO 28/2962, British Embassy, Belgrade, 29 November 1976.

34 TNA, FCO 28/2962, Brezhnev's Visit to Yugoslavia, 22 November 1976. 
de l'influence soviétique en Europe du Sud-Est et dans le Bassin Méditerranéen ont incité les dirigeants de Moscou à manifester aux Yougoslaves un intérêt plus que 'fraternel' et à leur ouvrir systématiquement de larges possibilités de coopération, en particulier dans le domaine économique". ${ }^{35}$ These concerns, largely shared by the Nine and the US Administration, confirmed the need for the EC to counter Soviet pressures by enlarging the fields of cooperation with Yugoslavia in the years to come. ${ }^{36}$ It was no coincidence that, during the very days of Brezhnev's visit to Belgrade, the EC Council confirmed that the President-in-Office of the EC Council and a European Commissioner would visit Belgrade on 1 and 2 December "to manifest, by their presence, EC's will to reinforce its relations with Yugoslavia". ${ }^{37}$ The EC mission resulted in the signing of a Joint Statement by the Yugoslav Prime Minister, Džemal Bijedic, and the Community representatives. The statement, which defined Yugoslavia as a non-aligned, European and Mediterranean country, referred in warm but general terms to a number of ways in which economic cooperation between Yugoslavia and the EC might be strengthened. ${ }^{38}$

\section{From the Joint Declaration to the Co-operation Agreement (1976-1980)}

After the signing of the 1976 declaration, the question arouse as to how practical follow-up could be given to this general statement of interest. In 1977, the EC Commission embarked on an intensive and accelerated program of work with the Yugoslavs, involving several meetings of three EC-Yugoslav joint committees on agricultural, industrial and economic cooperation. ${ }^{39}$ Their task was to identify the nature and content of a new bilateral agreement. ${ }^{40}$ However, the first round of negotiations (February-April 1978) was not successful. ${ }^{41}$ The political necessity to respect Yugoslavia's non-aligned status forced the two parties to negotiate a non-preferential agreement, since a preferential treatment would have cut across the Yugoslav policy of strict non-alignment. ${ }^{42}$ As declared on 28 March 1977 by a

35 AMAE, DE 76-80, 4835, Note, La politique extérieure yougoslave et les Grands, Paris, le 20 novembre 1976.

36 AMAE, DE 76-80, 4840, Yougoslavie-URSS, Belgrade le 12 Janvier 1977; HAEC, BAC 971986 19, Office of Mr. Soames, Note to Mr. Gundelach, Relations with Yugoslavia, Bruxelles, 17 December 1976; TNA, FCO 28/3166, EEC/Yugoslavia, 8 September 1977.

37 Archives of the Council of the European Union (ACEU), Extrait du: "Communiqué à la Presse" de la 418ème Session du Conseil tenue à Bruxelles, le 16/11/76. Doc. 1261/76 (Presse 141).

38 TNA, FCO 98/118, Council of Ministers (Foreign Affairs), Brussels, 13/14 December 1976.

39 TNA, FCO 28/3166, EEC/Yugoslavia, 8 September 1977.

40 HAEC, BAC 971986 19, Yougoslavie, Note de synthèse pour le Vice-président Haferkamp, Bruxelles, le 28 juin 1977.

41 HAEC, BAC 971986 22, Projet d'exposé de M. le Vice Président Haferkamp au Conseil des Ministres du 25 juillet 1978, Bruxelles, le 24 Juillet 1978.

42 HAEC, BAC 97 1986, Note à l'attention de Monsieur Duchateau, renouvellement de l'Accord de coopération CEE-Yougoslavie. Commentaires sur les propositions yougoslaves, Bruxelles, 
Member of the Yugoslav Federal Executive Council to the newly elected president of the EC Commission, Roy Jenkins: "A preferential agreement would not be acceptable, neither politically nor economically". ${ }^{43}$ However, the non-preferential approach had great limitations, since all non-preferential trade concessions given to Yugoslavia could be automatically extended, according to the GATT rules, to all EC trade partners. This was clearly against the Nine's economic interests.

The impasse was overcome in June 1978, when EC Commissioner for External Relations, Wilhelm Haferkamp, proposed that his Yugoslav counterparts should negotiate a co-operation agreement envisaging a preferential trade system within the framework of EC's "Global Mediterranean Policy". ${ }^{44}$ This proposal would benefit EC-Yugoslav relations for several reasons. First, it would offer a legal background for the reduction of EC barriers to Yugoslavia's exports on the basis of agreements already concluded by the EC with other Mediterranean countries. ${ }^{45}$ Second, it would pave the way for bilateral cooperation in several economic fields. Third, it would represent a step forward towards the policy of EC rapprochement to Yugoslavia in the perspective of the post-Tito era. ${ }^{46}$ Faced with the need to solve the deficit of its trade balance, Belgrade accepted the EC's preferential approach, on condition that it would be publicly presented as sui generis. ${ }^{47}$ The EC Commission was indeed aware of the importance of formally preserving Yugoslavia's nonaligned stance. ${ }^{48}$ As noted by Haferkamp: "Cette politique constitue en effet le pilier de la position extérieure yougoslave. La Communauté doit la respecter". ${ }^{49}$

le 24 IV 1978; TNA 73/239, Yugoslavia and the EEC, 10 June 1976; AMAE, DE 76-80, 4845, Compte rendu de la visite du Secrétaire d'Etat en Yougoslavie, Paris, le 15 Juin 1978.

43 HAEC, BAC 971986 19, Note for the Record, Visit of Mr. Smole, Member of the Yugoslavian Federal Executive Council, on 28 March 1977, 30/3/1977.

44 HAEC, BAC 971986 22, Note de Dossier, Voyage de M. Haferkamp à Belgrade les 22 et 23 juin 1978, Bruxelles, le 26 juin 1978; BAC 97 198624, Note à l'attention de MM. les Membres de la Commission, Bruxelles, le 15 décembre 1978; On EC's Global Mediterranean Policy, see: Elena Calandri, "L'eterna incompiuta: la politica mediterranea tra sviluppo e sicurezza", in Elena Calandri (ed.), Il primato sfuggente. L'Europa e l'intervento per lo sviluppo (19572007), Milano: Franco Angeli, 2009, pp. 53-88, and Guia Migani, "La politique globale méditerranéenne de la CEE, 1970-1972" in Antonio Varsori and Guia Migani (eds.), Europe in the international arena during the 1970s: entering a different world, Bruxelles: Peter Lang, 2011, pp. 193-210.

45 See Guia Migani, "Re-Discovering the Mediterranean. First Tests of Coordination among the Nine", in Elena Calandri, Daniele Caviglia and Antonio Varsori (eds.), Politics and Diplomacy in the Mediterranean and the Middle East, London/New York: I. B. Tauris, 2012, pp. 49-60.

46 TNA, FCO 98/369, Council of Ministers (Foreign Affairs), Luxembourg, 16-17 October 1978.

47 HAEC, BAC 971986 22, Voyage de M. Haferkamp à Belgrade les 22 et 23 juin 1978, Bruxelles, le 26 juin 1978.

48 HAEC, BAC 971986 22, Projet de Speaking Note, Bruxelles, le 7 juillet 1978.

49 HAEC, BAC 971986 22, Projet de communication de la Commission au Conseil, Bruxelles, le 10 juillet 1978 . 
On 17 October 1978, the EC Council discussed Haferkamp's proposal. In the opening session of the meeting, the EC commissioner stated: "Tout le monde sait bien que derrière ce problème économique se profile une évolution politique de notre partenaire yougoslave que la Communauté doit soutenir". ${ }^{50}$

Haferkamp's proposal was endorsed unanimously by the Nine. ${ }^{51}$ The Council approved the new Commission's mandate on 6 February 1979. Negotiations with Yugoslavia officially opened on 2 July $1979 .^{52}$

Several international issues affected EC-Yugoslav negotiations throughout the rest of the year ${ }^{53}$. From the EC's viewpoint, the main issue regarded the Nine's reluctance to grant several Yugoslav products access to the EC market. Belgrade instead was mainly concerned with the evolution of the USSR's negative attitudes towards Yugoslavia, which had emerged during Tito's visit to Moscow in August $1979^{54}$. In particular, Belgrade feared the radicalisation of an ideological confrontation with Moscow and the rise of Kominformist forces within the country, which would be able to exploit inter-republican contrasts and weaken the federation. ${ }^{55}$ The Yugoslavian government was also concerned about the Balkans' geopolitical stability, due to Greece's imminent accession to the EC and growing tensions between Belgrade and Sofia about the Macedonian issue. ${ }^{56}$ Last but not least, Belgrade was worried about the future of the NAM. ${ }^{57}$ Indeed, Vietnam's invasion of Cambodia in January 1979 was portrayed by Belgrade as patent aggression against a non-aligned country, whereas Moscow's close relations with countries like Cuba, Ethiopia, Mozambique and South Yemen were considered as a catastrophe for the autonomy of the Movement. ${ }^{58}$ Yugoslavia's efforts to strengthen its

50 HAEC, BAC 971986 23, Speaking Note à l'attention de Monsieur Haferkamp, Yougoslavie - Conseil des Affaires Etrangères du 17 octobre, Bruxelles, le 13 octobre 1973.

51 TNA, FCO 98/369, Council of Foreign Affairs 17 October: Luxembourg, EEC/Yugoslavia.

52 HAEC, BAC 971986 22, Note de Dossier, Yougoslavie-Mission de M. Duchateau à Belgrade du 14 au 17 juillet 1979, Bruxelles, le 12 juillet 1979.

53 HAEU, EN, 2781, Note de Dossier, Yougoslavie-CEE, Bruxelles, le 14 Mai 1979.

54 TNA, FCO 28/3157, Canadian Delegation to NATO, Tito's visit to the USSR, August 25, 1977; FCO 28/3916, Info Belgrade-Visit to USSR by President Tito, 22 May 1979.

55 TNA, FCO 28/3157, Tito's visit to Moscow, 2 September 1977; Soviet Interest in Yugoslav Republics, 14 July 1977.

56 TNA, FCO 28/3924, Visit by the Minister of State to Belgrade, 9 January 1979; FCO 28/3916, British Embassy, Belgrade, Yugoslav-Soviet Relations, 28 February 1979; FCO 28/3916, British Embassy Belgrade, Yugoslav-Soviet Relations, 24 January 1979.

57 TNA, FCO 28/3924, Record of Talks between the Yugoslav Minister for Foreign Affairs and the Minister of State for Foreign and Commonwealth Affairs at 12.30 pm on 4 January 1979 in Belgrade, undated.

58 TNA, FCO 28/3921, British Embassy Belgrade, China/Vietnam, 28 February 1979; FCO 28/3917, Record of a call by the Yugoslav Ambassador on Mr Bullard in the FCO on Friday 20 April 1979 at 11.30 am; FCO 28/3916, Inappropriate analogies of TASS (Borba, Thursday, November, 1979, p. 7, c. 6). 
role among non-aligned and developing countries (G77) affected negotiations with the Community. ${ }^{59}$ This emerged during the visit to Belgrade on 15 March 1979 by the Director of the DG I, Roy Denman, who noted evident divisions among the Yugoslavs vis-à-vis the ongoing negotiations with the EC: "La nouvelle approche de la Communauté, principalement dans le domaine commercial, ne reçoit pas une adhésion complète du côté yougoslave. L'école non préférentielle et tiers-mondiste qui est celle du Ministère du commerce extérieur semble regagner du terrain (...)". Nevertheless, according to Denman, the EC was obliged to insist on its preferential approach which was the only way to strengthen bilateral relations with Belgrade in a future perspective. ${ }^{60}$

The turning point in EC-Yugoslav negotiations was the Soviet invasion of Afghanistan in December 1979. This event nourished Western suspicious of some "grandiose Soviet scheme" behind Moscow's policy which might include Yugoslavia. ${ }^{61}$ Uncertainty about Soviet plans was flanked by growing divisions within the NAM in condemning Soviet intervention in Afghanistan and by the deterioration of Tito's health in January 1980. Faced with these challenges, the Yugoslav ambassador in Brussels told Jenkins that he hoped to devise a straight procedure of negotiation between the Community and his government at political level. ${ }^{62}$ The request was welcomed by the Nine, who, on 15 January, agreed on the need to sustain Belgrade in this delicate political conjuncture. ${ }^{63}$ The final round of negotiations took place in Belgrade in February 1980. Closer relationship with the Community was weaved with extreme discretion in order to avoid any danger of any USSR countermove. As stressed by the Yugoslav representative to Jenkins, "safeguarding Yugoslav independence without provoking the Soviet Union to precipitate action must now be one of the key issues to be examined by the West". Therefore, as in 1976, EC-Yugoslav relations should not appear as a Western plan to include Yugoslavia in the Western sphere of influence. On 28-29 February 1980, Jenkins went to Belgrade to set the seal on the negotiation for a sui generis Co-operation agreement, which was eventually

59 TNA, FCO 28/3924, Secretary of State, Visits to Yugoslavia and the Lebanon, 12 January 1979.

60 HAEC, BAC 971986 27, Note à l'attention de Monsieur Haferkamp, Bruxelles, le 5 juillet 1979.

61 Tvrtko Jakovina, "Sovjetska intervencija u Afganistanu 1979. i Titova smrt", Historijski zbornik, No. 60, 2007, pp. 295-320; Anatoly Dobrynin, In confidence: Moscow's ambassador to America's six Cold War presidents (1962-1986), New York: Times Books, Random House, 1995, p. 446; Odd Arne Westad, The Global Cold War. Third World Interventions and the Making of Our Times, Cambridge: Cambridge University Press, 2007, pp. 321-26.

62 HAEU, EN, 2782, Note for the Record, The Ambassador of Yugoslavia, Mr. Jevtic, 10 January 1980.

63 Ante Batović and Branko Kasalo, "Britanski i američki izvori o smrti Josipa Broza Tita" in ČSP, No. 1, 2012, p. 13. 
signed on 2 April 1980. ${ }^{64}$ Before Jenkins' visit, upon explicit Yugoslav request, the EC Commission urged the President of the European Parliament (EP), Emilio Colombo, to limit parliamentary debates on Yugoslavia ${ }^{65}$ : "Il est clair qu'une négociation si délicate ne doit pas être mise sur la place publique. Différentes interventions de parlementaires européens qui ont par example mentionné comme solution pour la Yougoslavie de s'associer à la Communauté sont particulièrement préoccupantes. Il est clair que si les Yougoslaves apprennent par la presse qu'un tel courant se dégage, ceci risquerai de remettre en cause les efforts qu'ils font actuellement pour conclure. Dans ces conditions je crois que nous avons tout intérêt à éviter un débat en séance plénière à la prochaine session du Parlement européen" ${ }^{66}$ The EC-Yugoslavia Co-operation agreement had indefinite duration and aimed at balancing bilateral trade through a preferential and non-reciprocal system envisaging substantial reductions of custom duties for a number of agricultural and industrial products. It also set up new mechanisms of cooperation in several economic fields, including finance. ${ }^{67}$ In addition, the two parties established a Co-operation Council which was to become the main forum for bilateral economic negotiations throughout the 1980s ${ }^{68}$ Both the EC and Yugoslavia depicted the Agreement as a milestone for future relations. The Yugoslav representatives stressed the importance of having achieved a "contractual" link with the Community which formally respected Belgrade's autonomy and offered guarantees for Yugoslavia's economic stability.

For the Nine, the agreement symbolised EC's support to Yugoslavia's stability in the perspective of the post-Tito era and, at the same time, preserved its non-aligned stance. ${ }^{69}$ Furthermore, as declared by US President Jimmy Carter to Jenkins in January 1980, the EC's Yugoslav policy enjoyed Washington's full support. Since Haferkamp's initiative in 1978, US traditional criticism to EC's network of preferential agreements in the Mediterranean region had indeed not

64 HAEU, EN, 2782, President, Your Visit to Yugoslavia, 5 March 1980; HAEC, BAC 971986 30, Vice President Haferkamp, President Jenkins' visit to Yugoslavia, 27-29 February 1980, Brussels, 6 March 1980.

65 HAEC, BAC 971986 30, President, Yugoslavia, 4 February 1980.

66 HAEC, BAC 971986 30, Note à l'attention de Monsieur Denman, Résultat des travaux de la Commission des Relations extérieures et de la Commission politique du Parlement européen sur le projet d'accord entre la Yougoslavie et la Communauté, Bruxelles, 31 Janvier 1980.

67 HAEU, EN, 2782, Europe Information, Relations extérieures, Edition provisoire 30/80, La Communauté Européenne et la Yougoslavie. Cooperation included the following fields: finance, industry, energy, scientific and technological research, agriculture, transport, tourism, environment, fisheries, labour.

68 Ibid.

69 HAEC, BAC 971986 28, Éléments de l'intervention de Monsieur Haferkamp, Yougoslavie - Conseil du 18 Mars 1980, Bruxelles, le 14 mars 1980; HAEU, EN, 2783, Note à l'attention du Président, visite du Ministre Andov, 12 Février 1981; Akten zur Auswärtigen Politik der Bundesrepublik Deutschland 1980, doc. 76. 
concerned Yugoslavia, whose economic link to the Community was deemed by Carter to be a Western priority. ${ }^{70}$

\section{The EC and Yugoslavia after Tito's death (1980-1985)}

After Tito's death, on 4 May 1980, the EC continued its traditional "low profile" policy towards Yugoslavia ${ }^{71}$. The Community's support for Belgrade took place in an atmosphere of growing confrontation among the superpowers. ${ }^{72}$ In 1980 , Western media and diplomacies frequently discussed the problem of Soviet hostile plans in the Balkans. In keeping with Ronald Reagan's anti-Soviet rhetoric ${ }^{73}$, the New York Times observed that, faced with Soviet expansionism in Afghanistan, Tito "had chosen the worst moment to die", while the Christian Monitor Observer caricaturised Yugoslavia as a helpless widow who received the visit of a sinister Russian whispering: "I'm your long-lost uncle. I'm here to take care of you" ${ }^{74}$ These views, however extreme, corresponded to those of several Western European diplomatic reports, emphasising Moscow's strategic interests in taking advantage of Tito's death to regain control over Yugoslavia. ${ }^{75}$ Accordingly, as stressed on 30 June 1980 by the FRG delegation to NATO: "The West should show its interest in an independent, stable, economically strong Yugoslavia, but should avoid creating the impression that we want to urge Yugoslavia towards a one-sided western orientation or to the abandonment of its social order"76.

Therefore, in the early 1980s, the Nine and their NATO allies still regarded Yugoslavia as an hotbed of bipolar confrontation ${ }^{77}$, one of the major Western anxieties being the emergence of a weak Yugoslav leadership unable to cope with

70 HAEC, BAC 971986 30, Note de dossier, Visite du Président Jenkins à Washington Yougoslavie, Bruxelles, le 16 janvier 1980.

71 AMAE, DE 81-85, 5724, Conseil du 14 Septembre Relations avec la Yougoslavie, le 15 Septembre 1981.

72 AMAE, DE 76-80, 4840, Relations soviéto-yougoslaves, Moscou, le 3 Juin 1980; Visite à Belgrade de M. Kouznetsov, 11 Juillet 1980; Controverse avec l’Union Soviétique, le 17 mars 1980.

73 Beth A. Fischer, "US foreign policy under Reagan and Bush", in Melvyn P. Leffler and Odd Arne Westad (eds.), The Cambridge History of the Cold War, Vol. III, Cambridge: Cambridge University Press, 2010, pp. 269-272.

74 AMAE, DE 76-80, 4841, Ambassade de France aux Etats Unis, Décès du Maréchal Tito, Réactions et commentaires de la presse américaine, Washington, le 8 mai 1980.

75 TNA, FCO 28/4235, UKDEL NATO, Meeting of Permreps on Yugoslavia, 18 January 1980; FCO 28/4240, Yugoslavia: Valedictory despatch, Diplomatic report No. 125/80, 8 April, 1980; FCO 28/3687, NATO experts working groups on Soviet Union and Eastern Europe, 1979.

76 TNA, FCO 28/4240, Dolanc, British Embassy, Belgrade, 15 October 1980.

77 TNA, FCO 46/2322, Record of Anglo/Italian Politico/Military talks held at the Italian Ministry of Foreign Affairs on 28 November 1980, 22 December 1980. 
traditional Soviet pressures. ${ }^{78}$ Concerns about Moscow's plans in the Balkans combined with those regarding Yugoslavia's economic fragility and growing tension between the federal government and the single republics. According to the Nine's economic counsellors in Belgrade, Tito's death had occurred at a moment when it had become increasingly evident that Yugoslavia would suffer the effects of several external and internal factors which, together, would seriously jeopardise the country's economic health: the rising cost of energy at international level, the low productivity of labour, high deficit of the balance of payments, high rate of foreign indebtedness, and inflation. ${ }^{79}$ According to the economic counsellors, the right answer to growing economic disequilibrium was to strengthen the role of the central government and establish a system of uniform economic regulations at federal level. ${ }^{80}$ However, they also noted that: "Avec l'absence de Tito de la scène politique, le dirigeants politiques yougoslaves auront beaucoup plus de difficultés à procéder dans cette voie compte tenu de l'opposition des autorités républicaines. Si la situation actuelle yougoslave apparaît complexe et les perspectives futures du pays assez incertaines, cela est dû en grande partie à l'absence d'une autorité centrale qui ait le pouvoir de coordonner efficacement l'économie (...)" ${ }^{81}$ From their viewpoint, the West should welcome Belgrade's efforts to foster economic centralisation at federal level, even though this would imply the infringement of the single republics' constitutional prerogatives: "Dans le jugement que les diplomaties occidentales donnent sur le processus de démocratisation ultérieure en Yougoslavie, elles ne peuvent pas ne pas tenir compte des risques politiques que la faiblesse d'une autorité économique fédérale (Etat ou parti) entraîne pour un pays comme la Yougoslavie, où se manifestent des tendances structurelles au déséquilibre économique et à la fragmentation du marché". ${ }^{82}$ The imperative of sustaining Yugoslavia's stability, strongly advocated by the Italian Government, drove the EC to strengthen relations with Belgrade within the Co-operation agreement ${ }^{83}$ and conclude a new trade protocol on 15 January 1982 to regulate trade relations between Yugoslavia and Greece, after the latter's accession to the EC in $1981 .^{84}$

78 AMAE, DE 76-80, 4840, Ambassade de France en Yougoslavie, Délégations économiques soviétique, américaine et chinoise à Belgrade, Belgrade, le 9 juin 1980.

79 ACEU, Rapport des Conseillers Commerciaux des Pays de la Communauté Economique Européenne en Yougoslavie (22 ${ }^{\mathrm{ème}}$ rapport), Bruxelles, le 9 avril 1981.

80 ACEU, Rapport des Conseillers Commerciaux des Pays de la Communauté Economique Européenne en Yougoslavie (20 ${ }^{\text {ème }}$ rapport), Bruxelles, le 26 février 1979.

81 Ibid.

82 ACEU, Rapport des Conseillers Commerciaux des Pays de la Communauté Economique Européenne en Yougoslavie ( $21^{\text {ème }}$ rapport), Bruxelles, le 25 juillet 1980.

83 ACEU, EN, 2783, Note à l'attention du President, Visite du Ministre ANDOV, Bruxelles, le 12 février 1981.

84 On the policy carried out by the Italian Government to sustain Yugoslavia's stability during the late 1980s, see Antonio Varsori, L'Italia e la fine della guerra fredda. La politica estera 
The political importance of EC-Yugoslav relations was confirmed in April 1983, when the Yugoslav Prime Minister, Milka Planinc, stressed to the president of the EC Commission, Gaston Thorn, Yugoslavia's will to strengthen relations with the Community. ${ }^{85}$

From 1980 to 1985, Belgrade's struggle against anti-unitary political forces in Yugoslavia did not affect bilateral dialogue within the Co-operation Council. Similarly, the Nine and the EC Commission did not release any overtly critical statement on this issue. The EC's policy of non-interference was dictated by the need to avoid any sign of Western interference which could hinder the political status quo in the Balkans. ${ }^{86}$ This emerged in a 1984 note by Albert Maes, a Community representative in Yugoslavia, which regarded Belgrade's protest against the Western media's and EP members' reports on the respect of political freedom in Yugoslavia ${ }^{87}$ : “(...) étant donné d'une part la situation économique et social très difficile que travers le pays et d'autre part le nombre et la nature relativement limités des entorses, une position très en flèche des Dix et notamment une démarche officielle ne pourrait qu'exacerber les autorités yougoslaves et provoquer une remise en cause par certains dirigeants de la politique de rapprochement avec l'Occident qui a été poursuivie au cours des dernières années dans le cadre du maintien d'une neutralité et d'un non alignement formel" ${ }^{88}$ In the early 1980s, this Community attitude was encouraged by the seemingly good results of economic cooperation with Yugoslavia. In this regard, the Nine's economic counsellors in Belgrade reported that positive results had been obtained in 1984 in some priority economic sectors, which indicated that the Federal authorities had managed to implement a stabilisation policy leading to a surplus of the balance of payments, reduction of the trade deficit and increase of industrial and agricultural production. ${ }^{89}$

dei governi Andreotti (1989-1992), Bologna: Il Mulino, 2013, pp. 121-157; ACEU, Relex III, Aide Mémoire, Relations avec la Yougoslavie, Bruxelles, le 27 mars 1987.

85 ACEU, EN, 2784, Note à l'attention de Monsieur Fielding, Visite de Mme Planinc, Premier Ministre de Yougoslavie-28 Avril, Bruxelles, le 10 mars 1983; HACEU, Co-operation between the European Economic Community and Yugoslavia, Minutes of the first meeting of the EEC-Yugoslavia Co-operation Council (Brussels, Tuesday 24 May 1983), Luxembourg, 18 June 1984.

86 AMAE, DE 81-85, 5724, La Yougoslavie et les Groupements économiques régionaux, le 20 septembre 1985.

87 AMAE, DE 81-85, 5724, Présidence Française - Visite à Strasbourg d'une délégation Parlementaire Yougoslave le 18 janvier 1984, le 15 décembre 1983.

88 HAEU, EN, 2784, Note à l'attention de Monsieur L. Fielding, Directeur Général, Belgrade, le 3 septembre 1984.

89 ACEU, Rapport des Conseillers Commerciaux des Pays de la Communauté Economique Européenne en Yougoslavie (25ème rapport), Bruxelles, le 18 juillet 1985; HACEU, Relex III, Aide Mémoire, Relations avec la Yougoslavie, Bruxelles, le 27 mars 1987. 
The EC's traditional views on Moscow's geopolitical interests in the Balkans were still present within Community Brussels even after Mikhail Gorbachev's election to the head of the CPSU in 1985. The joint reports of the Nine's economic counsellors in Belgrade on Yugoslavia show that, from the Community's viewpoint, no major political changes were taking place within the Soviet bloc as a result of Gorbachev's "new thinking". ${ }^{90}$ Despite the encouraging resumption of the superpowers' dialogue after Reagan's re-election to the US Presidency in $1984^{91}$, the seemingly stable Cold War framework in Europe persuaded the EC and Yugoslavia not to change the pattern of their traditional relationship..$^{92}$ Between 1985 and 1988, trade and financial agreements were signed to balance trade in the aftermath of the EC enlargement to Spain and Portugal, and to develop projects concerning infrastructures of common interest, in particular the trans-Yugoslavia motorway. ${ }^{93}$ The visit made by the President of the EC Commission, Jacques Delors, to Yugoslavia in July 1987 and the subsequent Co-operation Council's decision of 3 November 1987 to enlarge the provisions of the 1980 Agreement confirmed the EC's interest in developing relations with Belgrade. ${ }^{94}$ It was in fact the opinion of the General Secretariat of the EC Council that economic cooperation in trade and finance with Belgrade could become part of a long-term pattern. ${ }^{95}$ Bilateral relations, however, were perforce limited to a number of specifically economic areas, namely trade, finance, and technical, scientific and agricultural cooperation. ${ }^{96}$ Enhanced forms of cooperation between the two parties, such as an Association

90 See Archie Brown "The Gorbachev revolution and the end of the Cold War", in Melvyn P. Leffler and Odd Arne Westad (eds.), The Cambridge History of the Cold War, Vol. III, Cambridge: Cambridge University Press, 2010, p. 253.

91 David Reynolds, Summits: Six Meetings That Shaped The Twentieth Century, New York: Basic Books, 2007, pp. 343-400.

92 On EC's perception of Soviet bloc's apparent stability during the first years of Gorbachev's leadership see: Jacques Delors, L'Unité d'un homme: entretiens avec Dominique Wolton, Paris: Editions Odile Jacob, 1994, p. 255. On Gorbachev's "new thinking" towards EastCentral Europe, see Jonathan Haslam, "1989: history is rewritten", in Silvio Pons and Federico Romero (eds.), Reinterpreting the End of the Cold War. Issues, interpretations, periodisation, London/New York: Frank Cass, 2005, p. 175.

93 ACEU, General Secretariat of the Council, Note for Members of the Working Party on the Mediterranean (Yugoslavia), Subject: Annotated draft agenda for the sixth meeting of the EEC-Yugoslavia Co-operation Committee, Bruxelles, 30 October 1987.

94 ACEU, COM(87) 508 final, Recommandation de Décision du Conseil relative à la conclusion d'un Protocole additionnel à l'Accord de Coopération entre la Communauté économique européenne et la République Socialiste Fédérative de Yougoslavie établissant un nouveau régime commercial, Bruxelles, le 16 octobre 1987.

95 ACEU, General Secretariat of the Council, Note for Members of the Working Party on the Mediterranean (Yugoslavia), doc. cit., 30 October 1987.

96 Ibid. 
agreement (envisaging political links and common institutions) were never openly discussed. This was due to the rigid bipolar order which still conditioned bilateral relations: as reiterated by Community and Yugoslav representatives during all the meetings of the Co-operation Council from 1980 to 1988, Yugoslavia's internal autonomy and non-aligned stance were the major preconditions for geopolitical stability and international détente in Europe, the Balkans and the Mediterranean basin. ${ }^{97}$ During the late 1980s, faced with growing centripetal trends in the country, the EC's imperative of sustaining Yugoslavia's international position was consequently translated into open support to the Yugoslav federal government's efforts to preserve the country's unity and stability. In addition, the simultaneous growth of nationalist rhetoric in Yugoslavia was not considered unusual in Communist states in those years. As noted by the historian Tony Judt: "In the era of Gorbachev, with the ideological legitimacy of Communism and its ruling party waning fast, patriotism offered an alternative way of securing a hold on power". ${ }^{98}$

EC-Yugoslav relations drastically changed only in the aftermath of the geopolitical earthquake which caused the rapid collapse of all East-Central European communist regimes from mid-November 1989 to the end of that year. ${ }^{99}$ Archival documents on EC-Yugoslav meetings in 1989 show that the European turmoil that took place in autumn 1989 was in fact an "unexpected revolution" coming as a "breathtaking surprise" to both Community and Yugoslav representatives. ${ }^{100}$ Indeed, until early November 1989, relations between the two parties had followed the traditional path described above. Even Italian attempts to strengthen relations with Belgrade within the broader framework of the "Iniziativa Adriatica" were mainly based on an economically oriented cooperation. ${ }^{101}$ This traditional

97 ACEU, Co-operation between the European Economic Community and Yugoslavia, Projet de Procès-verbal de la sixième session du Conseil de Coopération CEE-Yougoslavie Niveau ministériel (Bruxelles, le 14 décembre 1987), Bruxelles, le 17 octobre 1988.

98 Tony Judt, Postwar. A History of Europe Since 1945, New York: Penguin, 2005, p. 671.

99 See Francesco Privitera, "The Relationship Between the Dismemberment of Yugoslavia and European Integration", in Jeffrey S. Morton, R. Craig Nation, Paul Forage and Stefano Bianchini (eds.), Reflections on the Balkan Wars. Ten Years after the Break Up of Yugoslavia, New York: Palgrave Macmillan, 2004, pp. 35-54.

100ACEU, General Secretariat of the Council, Note for Members of the Mediterranean Working Party (Yugoslavia), Annotated draft agenda for the eight meeting of the EECYugoslavia Co-operation Committee, MED 40/89 YU, Brussels, 8 November 1989; ACEU, Co-operation between the European Economic Community and Yugoslavia, Draft Minutes of the eight meeting of the EEC-Yugoslavia Co-operation Council at ministerial level (27 November 1989), Brussels, 26 April 1990. On the 1989 events defined as a "unexpected revolution", see John W. Young, "Western Europe and the end of the Cold War, 1979-1989", in Melvyn P. Leffler and Odd Arne Westad (eds.), The Cambridge History of the Cold War, Vol. III, Cambridge: Cambridge University Press, 2010, p. 306.

101 See Antonio Varsori, "Italy and the end of communism in Albania, 1989-1991", in Cold War History, No. 4, Vol. 12, 2012, p. 621. 
approach was radically shaken by the first anti-Communist revolutions in Poland, Hungary and the German Democratic Republic and, above all, by Gorbachev's refusal to use forces to maintain Communist regimes in East-Central Europe. ${ }^{102}$ The impending fall of the Soviet bloc made it clear that the Cold War framework which had constrained EC-Yugoslav relations so greatly since the mid-1970s was on the verge of collapse. This meant that a different road was open to Yugoslavia, i.e. the possibility of innovative political relations with the EC and, at the same time, the formal abandonment of its traditional non-aligned stance. This emerged clearly during the Co-operation Council's meeting of 27 November 1989 when, in sharp contrast with the past, neither Yugoslav nor EC representatives mentioned Yugoslavia's non-aligned stance as a factor of stability and détente in Europe and the Mediterranean. Conversely, faced with the crisis of legitimacy affecting all East-Central European Communist regimes, the Yugoslav Federal Secretary for Foreign Affairs, Budimir Loncar, declared to his Community counterparts that Yugoslavia was "more than ever in need of understanding and support from Europe and of new forms of co-operation with it". ${ }^{103}$ The Yugoslav representative noted that, when the first co-operation agreement had been signed in 1980, it had not been possible for either party to institutionalise relations to a greater degree. However, the "exceptional events taking place in Europe which might well herald the most important chapter in the history of Europe"104, urged both parties to place the question of future EC-Yugoslav relations on the agenda. Accordingly, the Yugoslav representative openly asked his Community counterparts, Presidentin-Office of the EC Council Roland Dumas and Commissioner Albert Matutes, to "improve the institutional framework of the relations between the two parties with the aim to place them at the level of Association with the European Community (...)" ${ }^{105}$ Yugoslavia's open request for future association with the EC in November 1989 clearly indicated that the end of the Cold War had definitively closed an era in EC-Yugoslav relations and opened the way to brand-new cooperation instruments to cope with the problem of Yugoslavia's stability. When in January 1990 inter-republican struggles had already reached a critical level, relations between the EC and Yugoslavia had to be re-thought from scratch by both parties.

102 Vojtech Mastny, "Did Gorbachev Liberate Eastern Europe?”, in Olav Njølstad (ed.), The last decade of the Cold War. From Conflict Escalation to Conflict Transformation, London/ New York: Frank Cass, 2005, pp. 336-354; Vladislav M. Zubok, A failed Empire. The Soviet Union in the Cold War from Stalin to Gorbachev, Chapel Hill: The University of North Carolina Press, 2007, pp. 321-335.

103 ACEU, Co-operation between the European Economic Community and Yugoslavia, Draft Minutes of the eight meeting of the EEC-Yugoslavia Co-operation Council at ministerial level (27 November 1989), Brussels, 26 April 1990.

104 Ibid.

105 Ibid. 


\section{Conclusions}

Analysis of EC-Yugoslav relations from 1976 to 1989 shows that the view according to which the EC carried out a "policy of neglect" towards Yugoslavia should be reconsidered. First, low-profile and unconditioned support to the Yugoslav federal government was, from the EC's viewpoint, the only viable road to preserve Yugoslavia's stability and independence, which had become a Community priority in the aftermath of the fall of détente in the mid-1970s. Second, Community and national archival sources show that the EC and its member states had clear knowledge of the political and economic issues affecting the Yugoslav federation since the early 1970s. It was the very awareness of Yugoslavia's internal fragility which forced the EC to develop intense relations with Belgrade during the late Cold War years. Third, Yugoslavia was more than a mere trading partner and labour exporter for the Community. Conversely, meaningful political rationales drove relations between the EC and Yugoslavia, which both shared the goal of maintaining stability and détente in Europe, the Balkans and the Mediterranean.

\section{Bibliography}

\section{Books}

Delors, Jacques, (1994), L'Unité d'un homme: entretiens avec Dominique Wolton, Paris: Editions Odile Jacob.

Dobrynin, Anatoly, (1995), In confidence: Moscow's ambassador to America's six Cold War presidents (1962-1986), New York: Times Books, Random House.

Garthoff, Raymond L., (1985), Détente and Confrontation: American-Soviet Relations from Nixon to Reagan, Washington D.C.: Brookings Institutions.

Gow, James, (2003), Triumph of the Lack of Will: International Diplomacy and the Yugoslav War, London: C. Hurst \& Co.

Heuser, Beatrice, (1989), Western "Containment" Policies in the Cold War. The Yugoslav Case, 1948-1953, London/New York: Routledge.

Judt, Tony, (2005), Postwar. A History of Europe Since 1945, New York: Penguin.

Lees, Lorraine M., (1997), Keeping Tito Afloat: The United States, Yugoslavia and the Cold War, University Park, PA: Penn State University Press.

Lucarelli, Sonia, (2000), Europe and the Breakup of Yugoslavia. A Political Failure in Search of Scholarly Explanation, The Hague: Kluwer Law International.

Meier, Viktor, (1999), Yugoslavia: A History of its demise, London and New York: Routledge.

Nuti, Leopoldo (ed.), (2009), The Crisis of Détente in Europe. From Helsinki to Gorbachev, London/New York: Routledge.

Pirjevec, Jože, (2001), Le guerre jugoslave 1991-1999, Torino: Einaudi.

Radeljić, Branislav, (2012), Europe and the Collapse of Yugoslavia. The role of Non-State Actors and European Diplomacy, London-New York: I. B. Tauris.

Ramet, Sabrina P., (2005), Thinking about Yugoslavia. Scholarly Debates about the Yugoslav Breakup and the Wars in Bosnia and Kosovo, New York: Cambridge University Press.

Reynolds, David, (2007), Summits: Six Meetings That Shaped The Twentieth Century, New York: Basic Books. 
Romano, Angela, (2009), From Détente in Europe to European Détente: How the West Shaped the Helsinki CSCE, Bruxelles: Peter Lang.

Romero, Federico, (2009), Storia della guerra fredda. L'ultimo conflitto per l'Europa, Torino: Einaudi.

Westad, Odd Arne (ed.), (1997), The Fall of Détente: Soviet-American Relations during the Carter Years, Oslo: Scandinavian University Press.

Varsori, Antonio, (2013), L'Italia e la fine della guerra fredda. La politica estera dei governi Andreotti (1989-1992), Bologna: Il Mulino.

Westad, Odd Arne, (2007), The Global Cold War. Third World Interventions and the Making of Our Times, Cambridge: Cambridge University Press.

Zubok, Vladislav M., (2007), A failed Empire. The Soviet Union in the Cold War from Stalin to Gorbachev, Chapel Hill: The University of North Carolina Press.

\section{Studies within a volume}

Brown, Archie, (2010), "The Gorbachev revolution and the end of the Cold War", in Leffler, Melvyn P. and Westad, Odd Arne (eds.), The Cambridge History of the Cold War, Vol. III, Cambridge: Cambridge University Press, 244-266.

Calandri, Elena, (2009), "L'eterna incompiuta: la politica mediterranea tra sviluppo e sicurezza", in Calandri, Elena (ed.), Il primato sfuggente. L'Europa e l'intervento per lo sviluppo (19572007), Milano: Franco Angeli, 53-88.

Fischer, Beth A., (2010), "US foreign policy under Reagan and Bush", in Leffler, Melvyn P. and Westad, Odd Arne (eds.), The Cambridge History of the Cold War, Vol. III, Cambridge: Cambridge University Press, 267-288.

Haslam, Jonathan, (2005), "1989: history is rewritten”, in Pons, Silvio and Romero, Federico (eds.), Reinterpreting the End of the Cold War. Issues, interpretations, periodisation, London/ New York: Frank Cass, 165-178.

Mastny, Vojtech, (2005), "Did Gorbachev Liberate Eastern Europe?”, in Njølstad, Olav (ed.), The last decade of the Cold War. From Conflict Escalation to Conflict Transformation, London/New York: Frank Cass, 336-354.

Migani, Guia, (2011), "La politique globale méditerranéenne de la CEE, 1970-1972" in Varsori, Antonio and Migani, Guia (eds.), Europe in the international arena during the 1970s: entering a different world, Bruxelles: Peter Lang, 193-210.

Migani, Guia, (2012), "Re-Discovering the Mediterranean. First Tests of Coordination among the Nine", in Calandri, Elena, Caviglia, Daniele and Varsori, Antonio (eds.), Politics and Diplomacy in the Mediterranean and the Middle East, London/New York: I. B. Tauris, 49-60.

Pavlowitch, Stevan K., (2007), "Yugoslavia: Why did It Collapse?", in Fouskas, Vassilis K. (ed.), The Politics of Conflict, London: Routledge, 147-154.

Pirjevec, Jože, (2004), "Yugoslavia and the Helsinki Process", in Meneguzzi Rostagni, Carla (ed.), The Helsinki Process. A Historical Reappraisal, Padova: CEDAM, 87-95.

Privitera, Francesco, (2004), "The Relationship Between the Dismemberment of Yugoslavia and European Integration", in Morton, Jeffrey S., Nation, R. Craig, Forage, Paul and Bianchini, Stefano (eds.), Reflections on the Balkan Wars. Ten Years after the Break Up of Yugoslavia, New York: Palgrave Macmillan, 35-54.

Njølstad, Olav, (2010), “The collapse of superpower détente, 1975-1980”, in Leffler, Melvyn P. and Westad, Odd Arne (eds.), The Cambridge History of the Cold War, Vol. III, Cambridge: Cambridge University Press, 135-155. 
Young, John W., (2010), "Western Europe and the end of the Cold War, 1979-1989”, in Leffler, Melvyn P. and Westad, Odd Arne (eds.), The Cambridge History of the Cold War, Vol. III, Cambridge: Cambridge University Press, 289-310.

\section{Studies in periodicals}

Artisien, Patrick F. R. and Holt, Stephen, (1980), "Yugoslavia and the EEC in the 1970s", in Journal of Common Market Studies, N. 4, Vol. 18, 355-369.

Batović, Ante and Kasalo, Branko, (2012), "Britanski i američki izvori o smrti Josipa Broza Tita” in $\check{C} S P$, N. 1, 7-22.

Biermann, Rafael, (2004), "Back to the roots. The European Community and the Dissolution of Yugoslavia - Policies under the Impact of Global Sea-Change" in Journal of European Integration History, No. 1, Vol. 10, 29.

Holt, Stephen and Stapleton, Ken, (1971), "Yugoslavia and The European Community 19581970", in Journal of Common Market Studies, No. 1, 47-57.

Jakovina, Tvrtko, (2007), "Sovjetska intervencija u Afganistanu 1979. i Titova smrt", Historijski zbornik, No. 60, 295-320.

Pedaliu, Effie G. H., (2009), “'A Sea of Confusion': The Mediterranean and Détente, 19691974”, Diplomatic History, No. 4, Vol. 33, 735-750.

Tsakaloyannis, Panos, (1981), "The Politics and Economics of EEC-Yugoslav Relations", in Journal of European Integration, No.1, Vol. 5, 29-52.

Varsori, Antonio, (2012), "Italy and the end of Communism in Albania", in Cold War History, No.4, Vol. 12, 615-635. 